\title{
Promoting Sustainable Development in Nigeria through Information and Communication Technology (Ict):
}

\author{
${ }^{1}$ Anyasi, F.I, ${ }^{2}$ Onianwa, C.U, ${ }^{3}$ Akpaida, V.O.A, ${ }^{4}$ Idiakheua, L.O, ${ }^{5}$ Ebegba, D \\ ${ }^{1,3,4}$ Department of Electrical and Electronics Engineering, Ambrose Alli University, P.M.B 14, Ekpoma. Edo \\ State, Nigeria \\ ${ }^{2}$ Department of Computer Sciences, Ambrose Alli University, P.M.B 14, Ekpoma. Edo State, Nigeria \\ ${ }^{5}$ Department of Electrical and Electronics Engineering, Petroleum Training Institute, P.M.B, 20, Effurun, Delta
} State, Nigeria.

\begin{abstract}
Significance of ICTs for sustainable development was examined arising from the fact that it has been put into the mainstream of development in Nigeria.

It is a known fact that Information and Communication Technology (ICT) is an indispensible part of the contemporary World, therefore its revolutionary potentials cannot be over-estimated. In recent years, developing Countries like Nigeria and International development communities have started taking concrete actions to incorporate Information and Communication technologies (ICTS) into their economic policies and development goals.

In this paper qualitative research method was used. Documented materials, reports, journals, newspapers etc. and personal observations were an essential part of the instruments for data gathering. Research questionnaires were structured to elicit the opinion of some respondents and ascertain their level of awareness of the impact of ICTs and their responses were found to be in consonance with the findings.

From the results obtained, it is obvious that ICTs are essential tools for sustainable socio-economic development in different key areas such as Education, Business and Commerce, Health, Governance etc.

Key Words: Information, Communication, Technology, Sustainable and Development
\end{abstract}

\section{Introduction}

The revolutionary potentials of ICTs lie in their capacities to instantaneously connect vast networks of individuals and organizations across great geographic distances at very little cost. As such ICTs have been key enablers of globalization, facilitating World-wide flows of information, capital, ideas, people and products. They have transformed business, markets and organizations, revolutionized learning and knowledge sharing, empowered citizens and communities and created significant socio-economic growth in many countries. In recent years, developing countries in Africa (Nigeria as a case study) and international development community have started taking concrete actions to incorporate Information and Communication Technology (ICT) into their economic policies and development agenda. This requires the implementation of sustainable measures to improve access to the internet and telecommunications infrastructure and increase ICT literacy, as well as development of local internet-based content. Nigeria like most developing countries still depends on content developed and managed in the developed World, and as a result, substantial costs are incurred while trying to access content. [1-4]

In general, ICT goals in Africa are; to establish an environment that encourages networking of services and applications, promoting internet access to exchange and access digital content, promoting e-education and online services, facilitating e-health, e-commerce and promoting programmes for goods and services, establishing e-government, strengthening network security, building and developing e-society and ICT human resources.[5-8]

Sustainable Development is a global crusade movement, a process rather than an end goal. To achieve and sustain development (sustainable development), revolutionary efficient, reliable and potential tools must be employed. These tools are the Information and Communication Technologies (ICTs) such as the Internet, mobile phones, e-mails, micro-computers amongst others., [9-11]

ICTs are new technologies that cannot be ignored in Africa especially for development. This is because ICTs are one of the main driving forces stimulating development and change in the digital age.

\section{Materials And Method}

This study is purely theoretical and based on research. The specific objective is to elicit the opinion of the people in order to be more acquainted with the significance of ICTs for sustainable development, with an attempt to mainstream the area of development into some of the key areas of the Nigerian economy. 
Both observed and documented materials for data gathering were used. These resources gave a good insight into what has been documented. The categories of documents used in the study include both primary and secondary sources. The primary sources where in the form of Government publications, newspapers, ITU news report on the internet, e-journals on ICTs etc. These had first-hand information on the researched area. The secondary sources of document include textbooks, reports of studies carried out by other investigators and other literatures relevant to this study. Questionnaires were also used to gather relevant information from some respondents (ICTs operators and end users). The purpose of this was to ascertain their opinion, attitude and level of awareness of the increasing role of ICT in some of the key areas of development in Nigeria. Their responses were based on the structured items provided in the questionnaire.

\section{DATA PRESENTATION OF RESPONDENTS}

In a bid to answer the five research questions posed for this research through the analysis of the data generated from the field, it becomes imperative to first analyse some of the bio-data of the respondents for validity purposes.

\section{GENDER OF RESPONDENTS}

From the 5-question structured questionnaire with both open and close ended questions, it was discovered that out of the 100 copies of the questionnaire administered, 69(69\%) respondents were males, while the remaining $31(31 \%)$ were females. These are shown in Figure 1.

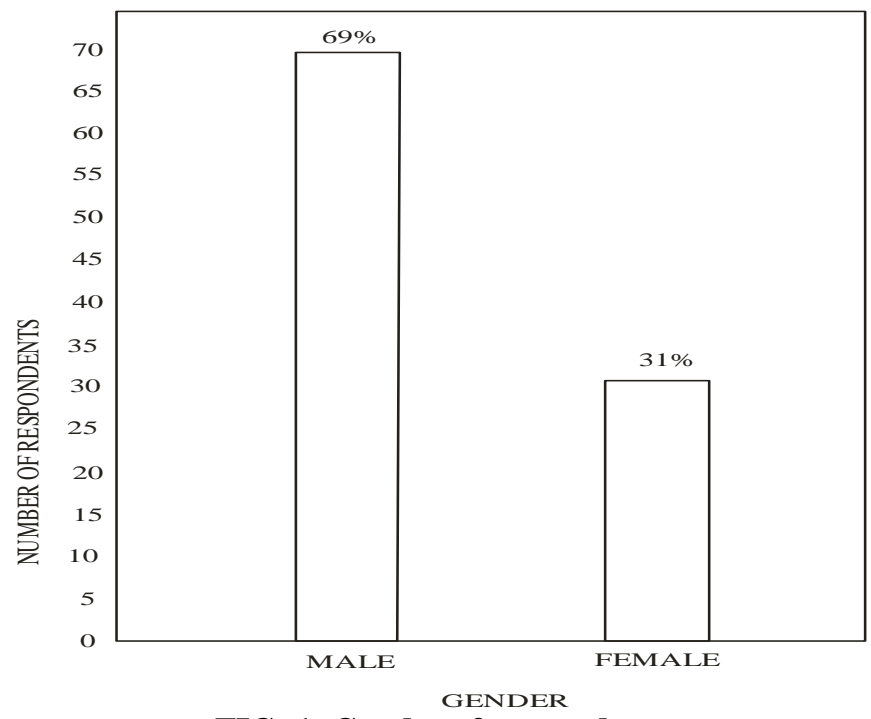

FIG. 1: Gender of respondents

\section{EDUCATION LEVEL}

Figure 2 shows the level of education of the 100 respondents. Majority of respondents reportedly have attained a basic to medium level of education, $13 \%$ have completed primary school, $41 \%$ have completed WAEC/NECO education, 23\% had HND/B.Sc., 15\% already had Master's degree and about $8 \%$ of the respondents have no formal education.

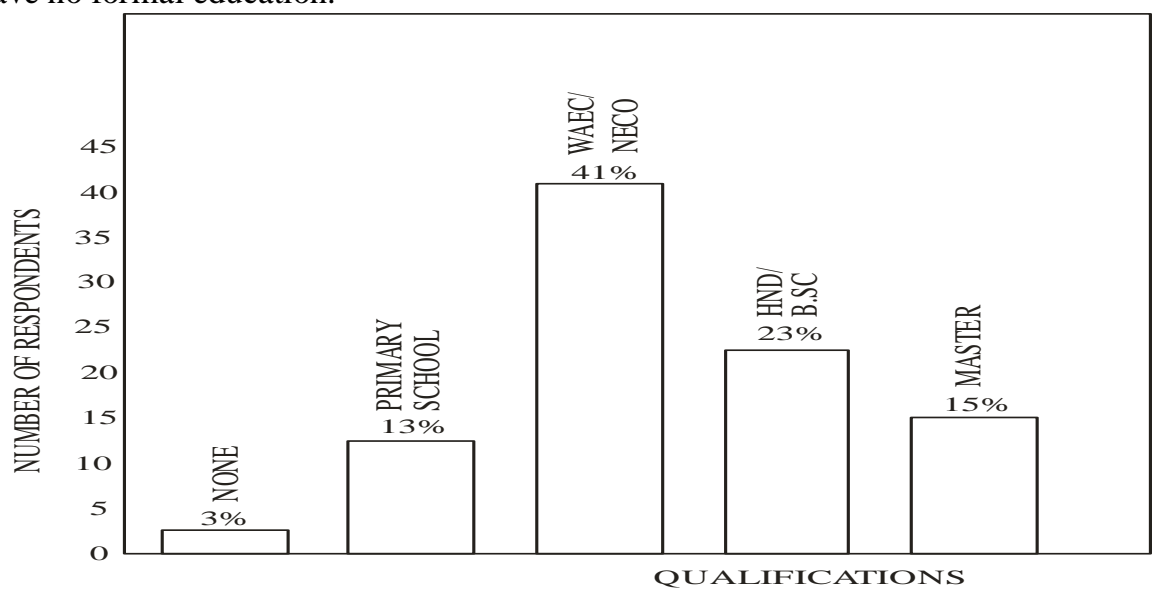

FIG. 2: Level of Education of Respondents 


\section{AGE DISTRIBUTION OF RESPONDENTS}

The data on the age distribution among the respondents showed that out of the 100 respondents, majority were with the age bracket of $26-45,(52 \%), 27 \%$ of the interviewed respondents where youths between the ages of 18-25 years, $12 \%$ fall within 46-65 years while the remaining $9 \%$ are from age 66 and above.

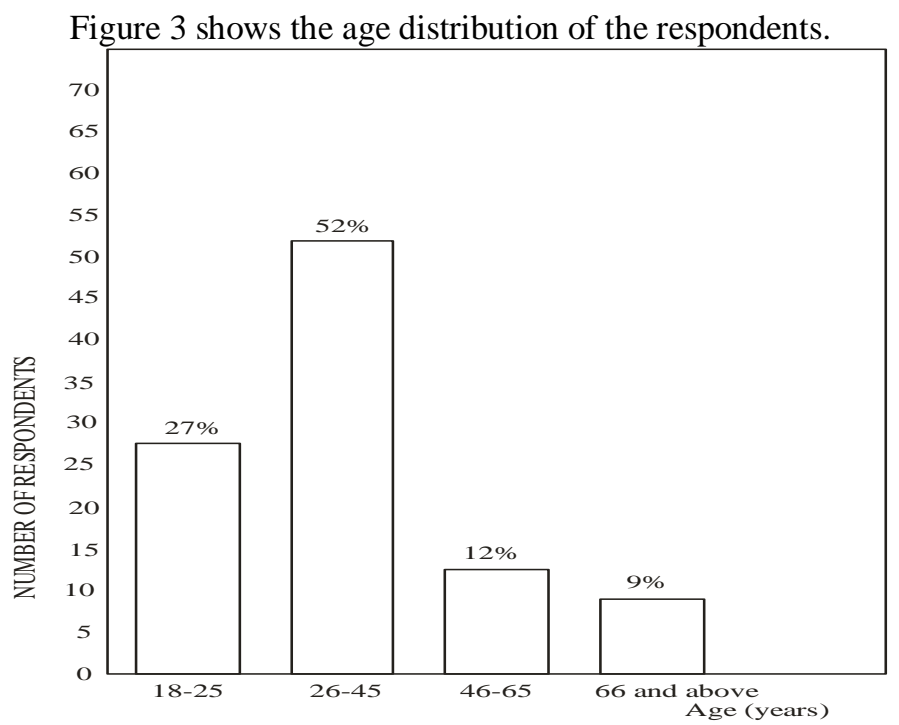

FIG.: 3: Age distribution of respondents

\section{RESEARCH QUESTION 1}

\section{Results And Discussion}

What is the significance of ICTs for sustainable development in Africa?

Table 1: Significance of ICTs for sustainable development in Africa.

\begin{tabular}{|l|l|l|l|l|l|}
\hline S/N & $\begin{array}{l}\text { CATEGORY OF } \\
\text { RESPONCE }\end{array}$ & $\begin{array}{l}\text { TOTAL NO. OF } \\
\text { RESPONDENTS }\end{array}$ & $\begin{array}{l}\text { NO. OF } \\
\text { RESPONDENT } \\
\text { S }\end{array}$ & $\begin{array}{l}\text { TOTAL } \\
\text { PERCENTA } \\
\text { GE }\end{array}$ & $\begin{array}{l}\text { PERCENTA } \\
\text { GE } \\
\text { RESPONCE }\end{array}$ \\
\hline 1. & Improves education & 100 & 16 & $100 \%$ & $16 \%$ \\
\hline 2. & $\begin{array}{l}\text { Increases efficient/effective } \\
\text { healthcare services }\end{array}$ & 100 & 8 & $100 \%$ & $8 \%$ \\
\hline 3. & $\begin{array}{l}\text { Promotes banking and } \\
\text { commerce }\end{array}$ & 100 & 17 & $100 \%$ & $17 \%$ \\
\hline 4. & $\begin{array}{l}\text { Enhances access to and } \\
\text { delivery of Government } \\
\text { services }\end{array}$ & 100 & 12 & $100 \%$ & $5 \%$ \\
\hline 5. & $\begin{array}{l}\text { Promotes global recognition } \\
\text { and partnership }\end{array}$ & 100 & 15 & $100 \%$ & $12 \%$ \\
\hline 6. & Aids mass enlightenment & 100 & 11 & $100 \%$ & $15 \%$ \\
\hline 7. & $\begin{array}{l}\text { Promotes agricultural } \\
\text { development }\end{array}$ & 100 & 83 & $100 \%$ & $11 \%$ \\
\hline 8. & All of the above & 100 & - & $100 \%$ & $83 \%$ \\
\hline 9. & None of the above & 100 & & $100 \%$ & - \\
\hline
\end{tabular}

All the 100 respondents see ICTs as significant tools for sustainable development. As shown in Table $1,83 \%$ of the respondents chose all of the above option. They believe that ICTs have the potentials to improve education, increase efficient/effective healthcare services, promote banking and commerce, enhance access to and delivery of government services, promote global recognition and partnership, aids mass enlightenment and promote agricultural development.

From the remaining respondents, $16 \%$ believe that ICT can improve the quality of education, $8 \%$ believe it can increase efficient/effective healthcare services, $17 \%$ chose banking and commerce, while $5 \%$ confirmed that ICT can enhance access to and delivery of government services, $15 \%$ also believed that ICT aids mass enlightenment, $11 \%$ agricultural development, while $12 \%$ went for global recognition and partnership.

\section{RESEARCH QUESTION 2}

Technology?

What is Nigerians level of awareness of the increasing impact of Information and Communication 
Table 2: Nigerians level of awareness of the role of ICT

\begin{tabular}{|l|l|l|l|}
\hline S/N & CATEGORY OF RESPONSE & NO. OF RESPONSE & $\begin{array}{l}\text { PERCENTAGE } \\
\text { OF RESPONSE }\end{array}$ \\
\hline 1. & Yes & 93 & $93 \%$ \\
\hline 2. & No & 4 & $4 \%$ \\
\hline 3. & Undecided & 3 & $3 \%$ \\
\hline 4. & Total & 100 & $100 \%$ \\
\hline
\end{tabular}

Table 2 shows that majority of the respondents are very much aware of the growing role of ICT in economic development.

Out of the 100 respondents, 93(93\%) said they are aware of the impact of ICTs, 4(4\%) said they are not aware, while the remaining 3(3\%) respondents were undecided. That is they have not yet made a decision or choice about the impact of ICT. One of the factors responsible for this high level of awareness may be that the Nigerian media are performing their mass enlightenment function

\section{RESEARCH QUESTION 3}

What is the attitude of Nigerians towards the use of Information and Communication Technology?

Table 3: Attitude of Nigerians towards the use of ICT

\begin{tabular}{|l|l|l|l|}
\hline S/N & CATEGORY OF RESPONSE & $\begin{array}{l}\text { NO. } \\
\text { RESPONSE }\end{array}$ & $\begin{array}{l}\text { PERCENTAGE OF } \\
\text { RESPONSE }\end{array}$ \\
\hline 1. & Positive & 86 & $86 \%$ \\
\hline 2. & Negative & 5 & $5 \%$ \\
\hline 3. & Indifferent & 9 & $9 \%$ \\
\hline 4. & Total & 100 & $100 \%$ \\
\hline
\end{tabular}

As shown in Table 3, 86(86\%) respondents have a positive attitude towards the use of ICTS, $5(5 \%)$ respondents had negative feelings towards the utilisation of ICTs in promoting sustainable economic development, while the remaining 9 respondents $(9 \%)$ expressed indifference about ICTs and its fundamental role in promoting sustainable development. Some of the reasons given for a positive attitude towards the use of ICTs were; ICTs can improve the state of the nation, are relevant goals for developing country like Nigeria, ICTs can lead to development of goals that are fundamental to any society etc.

Those respondents who were negative and indifferent about the use of ICTs gave reasons such as past failures of such goals/programmes, lack of interest in Nigerian system to implement the use of ICTs in her development agenda, making reference to the items in research question 3.

\section{RESEARCH QUESTION 4}

In what ways can Information and Communication technology be incorporated into the development agenda of Nigeria?

Table 4: Ways ICTs can be incorporated into the development agenda of Nigeria

\begin{tabular}{|c|c|c|c|}
\hline $\mathbf{S} / \mathbf{N}$ & $\begin{array}{l}\text { CATEGORY } \\
\text { RESPONSE }\end{array}$ & NO. OF RESPONSE & $\begin{array}{l}\text { PERCENTAGE OF } \\
\text { RESPONSE }\end{array}$ \\
\hline 1. & $\begin{array}{l}\text { Enlightenment and } \\
\text { education of the people. }\end{array}$ & 24 & $24 \%$ \\
\hline 2. & $\begin{array}{l}\text { Implementing/incorporating } \\
\text { the philosophical basis of } \\
\text { ICTs. }\end{array}$ & 26 & $26 \%$ \\
\hline 3. & $\begin{array}{l}\text { Provision of necessary } \\
\text { infrastructure. }\end{array}$ & 11 & $11 \%$ \\
\hline 4. & $\begin{array}{l}\text { Through } \\
\text { government/annual budget }\end{array}$ & 39 & $39 \%$ \\
\hline 5. & TOTAL & 100 & $100 \%$ \\
\hline
\end{tabular}

Table 4 presents the data gotten from the open-ended items in the questionnaire. Out of the 100 respondents, 24(24\%) believed that ICTs can be incorporated into the development agenda of Nigeria through enlightenment and education of the people, 26(26\%) said through the implementation of the philosophical basis of ICTs, 11(11\%) of the respondents feel it is through the provision of necessary infrastructure, while the remaining 39 respondents (39\%) agreed that it is through the government/ annual budget. 


\section{RESEARCH QUESTION 5}

What are the various factors militating against the effective utilization of ICTs for sustainable development in Nigeria?

Table 5: The various factors militating against the effective utilization of ICTs for sustainable development in

\begin{tabular}{|l|l|l|l|l|l|}
\hline S/N & $\begin{array}{l}\text { CATEGORYOF } \\
\text { RESPONSE }\end{array}$ & $\begin{array}{l}\text { TOTAL NO. } \\
\text { OF } \\
\text { RESPONDE } \\
\text { NTS }\end{array}$ & $\begin{array}{l}\text { NO. OF } \\
\text { RESPONSE }\end{array}$ & $\begin{array}{l}\text { PERCENTAGE } \\
\text { OF RESPONSE }\end{array}$ & $\begin{array}{l}\text { TOTAL } \\
\text { PERCENTAGE }\end{array}$ \\
\hline 1. & $\begin{array}{l}\text { Poor } \\
\text { communication } \\
\text { network }\end{array}$ & 100 & 6 & $6 \%$ & $100 \%$ \\
\hline 2. & Poverty & 100 & 5 & $5 \%$ & $100 \%$ \\
\hline 3. & Illiteracy & 100 & 8 & $8 \%$ & $100 \%$ \\
\hline 4. & $\begin{array}{l}\text { Lack of Qualified } \\
\text { ICT personnel. }\end{array}$ & 100 & 7 & $7 \%$ & $100 \%$ \\
\hline 5. & $\begin{array}{l}\text { Lack of public } \\
\text { funding }\end{array}$ & 100 & 4 & $4 \%$ & $100 \%$ \\
\hline 6. & Poor power supplies & 100 & 9 & $9 \%$ & $100 \%$ \\
\hline 7. & All of the above & 100 & 91 & $91 \%$ & $100 \%$ \\
\hline 8. & None of the above & 100 & 0 & 0 & $100 \%$ \\
\hline
\end{tabular}

From items in the questionnaire, it was proven that all the respondents believed that there exist some problems militating against the effective utilisation of ICTs for sustainable development in Nigeria.

Table 5 presents the data gotten from the items in the questionnaire. Out of the 100 respondents, 91 respondents (91\%) chose " all of the above" option, which implies that the problems militating against the effective use of ICTs are; poor communication networks, poverty, illiteracy, poor power supply, etc. from the remaining respondents, 6 of them (6\%) chose poor communication network, 5 respondents (5\%) saw poverty as a factor, 8 of them (8\%) gave illiteracy as a problem, 7 respondents (7\%) agreed that lack of qualified ICT personnel is among the challenges, 4 respondents (4\%) pointed out lack of public funding and $9(9 \%)$ respondents also see poor power supplies as one of the major factors militating against the effective utilisation of ICTs for sustainable development in Nigeria.

\section{Discussion}

The findings of the study provided useful answers to the research questions; this was further proven to be in consonance with reactions of the respondents. Efforts were made to study and examine the significance of ICTs in advancing viable development in the Nigeria economy.

The data generated, presented and analyzed with aid of the questionnaire revealed that ICTs are indeed fundamental tools for sustainable development in Nigeria as they help to improve the quality of education, increase effective/efficient healthcare delivery services, promote banking and commerce, enhance access to and delivery of government services etc. (Table 5)

In addition, the data got indicated that Nigerians' level of awareness of the remarkable role of ICTs is relatively high as shown in Table 2, where $93 \%$ of the respondents said they are aware of the impact of ICTs. The high level of awareness must have informed their positive attitudes towards the effective utilization of ICTs as shown in Table 3; 86\% of the respondents expressed positive attitude, as they see the goals as being relevant for developing countries in Africa such as Nigeria. This notwithstanding, few respondents where either negative or indifferent in their attitude toward the use of ICTs because of its limitations amongst others. Nonetheless, all the respondents believed that ICTs can be incorporated into Nigerian development process. This to them, could be through enlightenment and education of the people, implementing and incorporating the necessary infrastructure and through Government annual budget.

Some of the factors militating against the effective utilization of ICTs for sustainable development where were also considered; $91 \%$ of the respondents saw all the items in the question as the factors hindering the effectiveness of ICTs. Some of these factors include poor communication network poor power supply, poverty, illiteracy etc.

\section{CONCLUSION}

From the result of this study, it has been seen from all indications that Information and Communication Technology (ICTs) are veritable tools for sustainable development in Africa, especially when they are incorporated into Nigeria development agenda. "ICTs if harnessed and accommodated in locally 
meaningful ways can provide a platform for advancing development agendas in ways that are sustainable in the longer term" [11].

By reducing the costs of information sharing, improving its timely availability and providing the opportunities to create networks between people sharing particular interests or information needs, ICTs have the potential to contribute to the improvement of socio-economic conditions in developing countries. This is possible when the three parties involved in this regard - Government, people and the media work as a team in harnessing the potentials of ICTs. When these resources are implemented in various institutions, organizations and corporations in Nigeria, the country would have achieved a high level of human capital development.

Furthermore, considering the fact that some factors were identified as problems militating against the effective utilization of ICTs for sustainable development in African Countries (Nigeria), there is the need for the researcher to propose some useful recommendations from which I can conclude my study.

\section{RECOMMENDATIONS}

In line with the research findings, the following are therefore recommended as a way forward into ensuring that ICTs are effectively utilized for development in Africa, and that they are properly annexed into Nigeria's development agenda. They are;

Africa leaders should as a matter of urgency formulate and implement policies that would enhance the deployment of ICTs for sustainable development. Nigeria started implementing its ICT policy in April 2001 after the Federal Executive Council approved it by establishing the National Information Technology Development Agency (NITDA), the implementing body. The policy enables/empowers NITDA to enter into a strategic alliances and joint ventures and to collaborate with the private sector to realise the specifics of the Country's vision of, "'making Nigeria IT capable Country in Africa and a key player in the information society through using ICTs as an engine for Sustainable Development and global competitiveness.

Outlined below are some of the objectives of Nigeria's ICT policy:

- To ensure that ICT resources are readily available to promote efficient national development.

- To guarantee that the country benefits maximally, and contributes meaningfully, by providing the global solutions to the challenges of the information age.

- To establish and develop ICT infrastructure and maximize its use nationwide.

- To create ICT awareness and ensure universal access in promoting ICT diffusion in all sectors of national life.

- To create an enabling environment and facilitate private sector (national and multinational) investment in the ICT sector.

- To empower the youth with ICT skills and prepare them for global competitiveness.

- To empower Nigerians to participate in software and ICT development

- To encourage local production and manufacture of ICT components in a competitive manner.

- To integrate ICT into the mainstream of education and training.

- To encourage government and private sector joint venture collaboration.

- To develop human capital with emphasis on creating and supporting a knowledge-based society.

- To build a mass pool of ICT literate manpower using the NYSC and other platforms as a train-the-trainer scheme for capacity-building.

Nigeria leaders in particular, need to create development awareness in the people through the media/ICTs. They should not forget to improve the standard of education by incorporating ICTs in schools curriculum. Africa countries like Nigeria, which has a serious power supply problem, need to declare a state of emergency on the sector so as to resolve the problem rather than depend on generators for power.

The time has come for Nigerian leaders to parley with Global System for Mobile Communication (GSM) network providers so that they can employ their services in sending developmental messages as part of their corporate responsibility to the country. There is also the need for the government to insist on the GSM operators to extend their network coverage to rural areas in Nigeria and not just to concentrate on the urban areas. This is because development without the rural population is no development. All these must be accomplished with quality service delivery.

Above all, the government, the people and the media in Nigeria, need to merge resources together in ensuring that Information and Communication Technologies are effectively utilized for Sustainable Development while incorporating the development goals into the development agenda of Africa with the sole aim of bridging the digital divide in a bid to actualize sustainable development. 


\section{References}

[1] ANYASI, F.I, OBIAZI, A.M.O AND EVBOGBAI, M.J.E "INFORMATION TECHNOLOGY IN ENGINEERING" INTERNATIONAL CONFERENCE ON RESEARCH AND CAPACITY BUILDING"15 ${ }^{\mathrm{TH}}$ TO $16^{\mathrm{TH}}$ SEPTEMBER, 2011. PAGE 133. UNIVERSITY OF GHANA, EAST LEGON, ACCRA GHANA.

[2] UNDP. (2001). Human Development Report. http://www.undp.org/hdr 2001/.

[3] M.C, ANAEKWE, “Information Technology: A tool for Sustainable Development in Science Education. Global Communicator, 2008. 1(1):32.

[4] A.U, NWABUEZE AND R.E, OZIOKO, R.E. "Information and Communication Technology for Sustainable Development in Nigeria", 2011

[5] F.P, OLISE, F.P. "Information and Communication Technologies (ICTs) and Sustainable Development in Africa": Mainstreaming the Millenium Development Goals (MDGs) into Nigeria's Development Agenda, 2010

[6] G. MARCELLE,. 'Gender Justice and ICTs"' 2000.http://www.un.org/womenwatch daw/csw/marcello.htm.

[7] L.A, OGUNSOLA, AND W.A, ABOYADE, "Information and Communication Technology in Nigeria": Revolution or Evolution. 2005. PP.7-14.

[8] G, Kennedy AND B, Davis, “Electronics and Communication Systems” 1999 (p.1).

[9] A.M, Hasna, “ Dimensions of Sustainability. Journal of Engineering for Sustanable Developoment”: Energy, Environment and Health . 2007. 2(1): 47-57.

[10] D, SOUTER,. "The Role of Information and Communication Technology (ICT) in Democratic Development. Journal of Policy Regulation and Strategy for Telecommunication Information and Media, 1999. 1:8;408.

[11] A, MAIYE AND K, Mc GRATH, “ICTs and sustainable development: a capability Perspective; AMCIS 2010 proceedings, paper 541. Available at http://aisel-aisnet.org/amcis2010/541 